\title{
Impact of design characteristics of daylight elements to creating healthy internal environment for school buildings evaluation the status of schools in mosul city
}

\author{
Ghada M. Younis ${ }^{1}$, Farah S. Abdulatif ${ }^{2}$, Waleed S. Mostafa ${ }^{3}$ \\ ${ }^{1}$ Departement of Architecture,Engineering collage, University of Mosul \\ ${ }^{2}$ Departement of Architecture,Engineering collage, University of Mosul \\ ${ }^{3}$ Departement of Architecture,Engineering collage, University of Mosul
}

\begin{tabular}{l} 
Article Info \\
\hline \\
Received Jun $12^{\text {th }}$, \\
\hline Keyword: \\
Daylight \\
Healthy Building \\
School \\
Solarization \\
Homogeneity
\end{tabular}

\begin{abstract}
This research deals with the impact of design characteristics that create attractive and healthy internal environments for a school building, as one of the most important issues on evaluating the random position of a local school building in Mosul city northern Iraq. The daylight effects factors that support the efficiency of interiors in a school building was discussed in this work, Where, the specific quality of design characteristics related to building components and daylight elements classes were used. The study employed (Velux Daylight Visualizer - 2012) to design the research methodology in order to evaluate three school building types in Mosul city. The gained results of this study confirmed that the design properties related to the factors of daylight have effective role in creating healthy interiors and increase educational productivity. Also, the gained result of this study can be considered as a useful reference for architects, planner, landscape and researchers that they work in Mosul municipality. The objective of this paper is to determine the key design properties affecting to achieve healthy spatial environment, which are related to two main daylight factors. First the solarization average for building at all. Second the homogeneity of daylight at work surface in classroom space.
\end{abstract}

\section{Corresponding Author:}

Ghada M. Younis,

Departement of Architecture, Collage of Engineering,

Mousl University,

Mosul,Iraq

Email: ghada_my65@yahoo.com

\section{Introduction}

School buildings are functional patterns buildings that provide efficient improving for their occupants. Few of external and internal design characteristics of school buildings have a role in determining health characteristics to be provided, including health factors derived from a natural environmental system of solarization and daylight as fundamental characteristics of formation internal environment of classroom 
spaces. The designer should have complete knowledge that can be listed as healthy design methods of building from the site, school building and then classroom dimensions and address random signature of buildings related to the efficiency of natural lighting solarization through testing some design characteristics with natural lighting efficiency indicators [1]. The local schools follow only three uniform patterns types of design without regard to the specificity of the location, direction, and access. Therefore, the proposed solutions as an attempt to raise the efficiency of the performance aspects of the classroom by proposing alternatives and possible treatments that achieve this to provide the right conditions for students to do their homework in the right way [1].

\section{Healthy building}

Sustainable design trends at beginning of its proposals were primarily concerned with energies and resources and motivating people to avoid environmental damage, but it failed to diagnose characteristics affecting human health and well-being in living and working environment, as well as to diagnose basic human needs of communication with nature. Through physical, emotional, mental, and spiritual aspects the following lines represented by - orientation of sustainability propositions - towards economic values and attention to environmental health only - has resulted in "designs" that have increased the alienation of man and his isolation from beneficial communication with the natural environment. Negative patterns were included under a concept of SBS; Sick Building Syndrome so, after a pursuit of sustainable design has been focused on energy conservation and environmental conservation. The sustainable design approaches have begun to focus on the human dimension, which has intrinsic values and specific values of life.[2] The basic human fundamental values have been expanded through the attitudes of humans in the environmental health equation scope, with recognizing how the environment based on mental health and human desire being and its corrosive productivity is influenced by the quality and quantity of continuous experience with nature (natural systems and processes) [2] The purpose of sustainable construction is "the creation and management of healthy environments based on the effective use of resources and ecological design.[3]

\subsection{Human Design}

To get perfect design the designer focuses on interactions between humans and the natural world, focusing on viability and ability of life of all components of the natural ecosystem. Many kinds of research have revealed that principle is deeply rooted in the need to preserve elements of ecosystem chain that allow human survival. Furthermore, this goal focusing on the design of human comfort that includes "improving the work environment and home", which its results are increased productivity, reduce tension and provide a positive impact on health. These strategies of the principle of (human design) focused mainly on improving the quality of life for human beings. [4]. A city is recognized according to the necessary and essential of it delivers harmony between the constant and the changing elements .[5] Updating the components of the urban environment also to deliver them in an appropriate technical level that provides the needs of both normal persons as well as people with special needs .[6] Sick Building Syndrome named as a green concept of design in order to change the course of its path towards the concerning occupants and their health for developing terms: Ecology Building, use of less toxic substances and improvement of internal air quality and use of values of health design proposals adopted in many of research (building biology). Building scientists, architects, and structural engineers have adopted a similar approach by ecologists to look at ecosystems, including symmetry, with a more dynamic view of building systems, occupants and larger environment. This view was described as an ecological building, which included the effects of building on its occupants as well as occupants of building [7]. This approach has been followed since 1981 and concepts that have been put forward and studied. The greening and dematerialization of building it must take place on every levelproduction, expenditure and regulation. The green plant has to begin everywhere, but the area of expenditure may be the place where fundamental initiatives have the utmost space for movement.[8] 


\subsection{Sick Building Syndrome}

Sick Building Syndrome refers to a description of occupants of patient's buildings and acute rest and health effects that appear to be related to time spent in a building, without the possibility of identifying a particular disease or cause. A World Health Organization report in 1984 indicated that 30\% of complaints about formation of new buildings around world related to indoor air quality [9], including indicators of phenomenon of ill-structured buildings (SBS) comes: Occupations of sick building are associated with acute discomfort and a lot of troubles, for example headache, irritation of throat or eye or nose, allergies, asthma, dry cough, dry skin, itching, dizziness, nausea, allergies, odors, difficulty concentrating as well as Nervous system, respiratory distress, and sinus congestion. Most complainants feel better soon after leaving the building, which appears to be related to time spent in a building, without specifying the cause or determining the disease. [10]

\subsection{Causes of building diseases}

Health Building International said that the cause of symptoms of diseases associated with buildings is due to pollution of the internal environment with viruses, bacteria, and fungi as well as unbalanced factors like cold, excess heat or air currents and humidity. Besides, there are other factors caused the same diseases associated with buildings like poor distribution of lighting, odours not desirable, overcrowding of spaces, lack of flexibility and oppose personal desires of different susceptibility of people to accept internal atmosphere. [11] The perfect design that related with diseases of buildings is based on various factors including what is climatic and what is psychological as follows:

1. Design factors: from site selection down to smallest detail in the design process (structure, orientation, space shapes, relationships, etc. design decisions are made for sake of complimentarily between different objectives. The desirability of some goals and at the same time underestimate should not neglect designer in making any decision to study the impact on the user's comfort and needs to be varied within the built environment. Any imbalance in the adoption of decisions or sequence will lead to negative effects on users of the building. [12]

2. Climate factors: The climate elements of the internal environment consist of heat, humidity, daylight and ventilation etc. Climate has an important influence on human life according to its activities. The climate design of building was identified by terms of shape, size, and direction. The design is a reaction or response of influencing factors thus, its requirement is the lowest climatic treatments for achieving overall comfort of humans within an internal environment.

3. Psychological factors: all factors of the internal environment that indirectly affect human health such as color, light, furniture, space, and forms ... etc [13].

Uses of SBS syndrome overlap significantly with factors related to physical properties of buildings, such as air quality, CO2 ratio, ionization ratio, humidity and temperature [14], [15] and many factors of rest lead to manifestations of patient buildings and many aspects of buildings can lead to serious diseases, physiological, psychological and mental and so can be counted building-related diseases [9].

\subsection{Relationship of transparent surfaces to health and climatic control in buildings}

The effect of transparent surfaces that called Green House Effect has main role in thermal transfer across building's envelope into space especially for facades that receive a large amount of sunlight, and solar radiation through the glass which can raise internal air temperature to values exceeding of the temperature of the air outside. The ordinary glass allows up to $80 \%$ of solar radiation to falling on it. A portion of the radiation that accounts for $95 \%$ of solar radiation energy is absorbed by internal surfaces of the building. Heat raised by the temperature of surfaces. This heat is emitted in the form of long radiated radiation, which is not allowed to go out through the window, therefore, solar radiation passes through glass. It remains inside the 
building's interior space, and climate design workers are advised to reduce solar thermal gain to receive large amounts of X-rays [9]. According to Durakovic, increase in energy consumption is linked with an increase in consumption of non-renewable energy source [16]. Minimization influence process of sterilization of spaces with no local researches that determines the minimum percentage areas of sterilization purposes, the researches should balance solarization of space sterilization where their recommendations are should remove the solar radiation and prevent it from entering the building in order to not increase the temperature the building.

\subsection{Importance of solar exposure on buildings}

The importance of solar exposure on health is its effect on the bacteria and different microbial species. It is known that solar energy entering a room is illuminated, warmed, dried, and especially important, it is sterilized and therefore has a physiological effect is useful. Good design and appropriate for environment overall work leads to a stimulating effect for the employees were relying on incorrect perception of possibility of ordinary glass to prevent part responsible for sterilization of sun (ultraviolet light) from entering into space and thus, the subject of bacterial extermination is imaginary "depending on" proportion of ultraviolet light entering space, and to approve this view is incorrect, because scientific truth has shown that the part reaches ground from ultraviolet radiation, which is the process of sterilization, passes a large part of it through glass into space. The bacterial activity is increasing in sunless area, as well as "that medical sources recombination need to exposure to sun and enough to be a precautionary measure against incidence of some diseases such as rickets. The response of the skin, eye, blood vessels, hormones, and or radiation gives the ability to continue to work regularly [9]. Therefore, the realization of the solar system remains important to the possibility of glass to insert ultraviolet light, and windows will be the main and important port of sun.

\section{Healthy Aspects of Indoor Spaces}

\subsection{Importance of providing day lighting on internal spaces}

Designer deals with light in different aspects Light is the ability to give inspiration, poetic and spiritual meanings to space, thus integrating a perception of light with realization of space and its uses allowed the architect to manage it brilliantly and using it successfully to show required meanings. [17] When providing appropriate daytime lighting for space the following liens are most important as below:

1. Providing psychological comfort of users of space. Introduction of lighting and presence of view from windows can connect user visually "to an external environment, and without the entry of daylight, lose contact with time and lose awareness of wear conditions and may feel lack of directivity [18]

2. Physiological effects of natural light appropriate amounts of ultraviolet rays from the sun help our bodies produce vitamin D, which keeps skin healthy and increases the production of white blood cells that help build the immune system. As well as microbial extermination or multiplication of bacterial activation caused by this radiation.

3. Visible light affects the regulation of some main biological functions in body hormones and enzymes have high sensitivity to sunlight and radiation.

4. Infra-red rays found in solar radiation are important in providing thermal radiation for indoor spaces in cold seasons of a year. [19]

5. Day lighting helps to show inner colours of space and make it clearer and closer to its natural colour, and that change in amounts of the lighting of day and quarterly gives an internal vision of fun and nonmonotonous.

6. Provision of daytime lighting (in a number of recent studies) has been linked to increased productivity. It stimulates a desire for energy production and activity, which results in increased work efficiency production. [20] 


\subsection{Important of Air quality and Air Ions}

Poor air quality (AQ) leading to the cause of SBS. This is due to faults in improper air conditioning, heating and ventilation systems due to unclean air filters and lack of sufficient fresh air, or reasons may be attributed to volatile organic compounds (VOCs); which are caused by some pollutants inside building such as pesticides, herbicides, biologic pesticides and biologic pollutants, such as mold and contaminants from some types of building materials. As well as the improper release of gases from some office machines, printing machines and light industrial chemicals used in building Ozone gas. [10] The most important air pollution solutions are ventilation and can help plants to purify air according to tests carried out by NASA, where fifty species of plants that have proven to be toxic gases including formaldehyde [15]. Air contains positive and negative ionic structures of different proportions depending on the nature of air based on the existence of a magnetic network connected to ground. If the proportion of positive ions is increased, the air becomes heavy "difficult to breathe, and usually a proportion of positive ions if the air is stagnant" and does not change. Ions are tiny (atom or molecule or group of molecules) carrying an electric charge of positive or negative and exist in the air. Varies concentration of ions in the atmosphere from one place to another significantly different where the geographical location in densely planted urban areas increase negative ions while in regions with high altitudes the negative ions are much larger than areas at sea level due to strong cosmic rays and ultraviolet radiation. Negative ion effect in internal pollutants is viruses and bacteria that need an environment with specific characteristics to live, including positive ions, they do not prefer an environment in which negative ions are abundant. Negative ions collide with tiny plankton and pollutants in the air such as bacteria, dust, pollen, cigarette smoke, and negative ions. Which continues to attract positive tiny plankton until become heavy enough to fall to the ground away from the air we breathe [9].

\section{Day lighting Factors Refflections on Education Building}

Daylight is one of the natural basic elements that contribute to rising health efficiency of educational buildings. The entering process of appropriate daylight in the building can increase the activity and concentration of students in educational spaces and reduce the exposure time of disease as well as increasing the contribution performance of the students using Different lighting techniques. Lighting may contribute retention of colours of materials and furniture inside educational space. The natural lighting has an important impact on buildings with long working times, which contribute to increasing visual comfort, unlike industrial lighting that may have a direct impact on students' performance. [21] Three Daylight sources were observed in areas with clear and partially cloudy skies, these sources are :( direct sunlight, direct skylight, light reflected from the ground, external fenders).Total Daylight is equal to the sum of direct sunlight that gathering from the diffused skylight and the reflected light from floors and buildings [22]. Buildings can be oriented in a way that contributes to the movement of the sun throughout the day, as a general rule, buildings with long axes to east and west have the best potential for receiving daylight. Day lighting and its intensity for deep spaces where the front of window decreases with the depth of space ( height of ceiling and shape of open) and this happens due to small space visible from planetarium, and lower rise of opens to top, this will lead to access the light to the depth of space [23]. The depth range of self-illumination is roughly determined in areas of the clear sky as Mosul city as much as twice height of the window. Where the depth that follows this range requires industrial light, so the addition systems of natural lighting appeared to reduce. The industrial lighting, systems have been designed to spread lighting on the work surface to balance lighting levels within space thus reducing dazzling which gets from windows that looked to be level of users vision. [24].

\subsection{External planetarium lighting}

The reason for the illumination of planetarium surrounding us during the day is the thickness of the layer of air surrounding the globe. The presence of some plankton of dust and water vapor in the atmosphere, these elements work to disperse and dispersal the solar radiation when passing through the atmosphere. This 
phenomenon is a basis of the lighting of the sky, without it exist, the planetarium will be almost dark. The intensity of the sky's light changes on a regular basis, depending on Earth's rotation around the sun during four seasons and its daily rotation around itself. Depending on the number of clouds covered there is an Overcast sky, Partial Sky, And Clear Sky. [20] As the city of Mosul and most of the cities of Iraq are classified within areas of full blue, so we will rely on this study analysis of intense celestial light and distribution method within planetarium with full clearing.

\subsection{Solar Spectrum}

Radiation of sun is electromagnetic radiation emitted from the sun toward the earth's surface to reach Earth's atmosphere in about eight minutes. The "radiation with different wavelengths called the solar spectrum and the effect of solar radiation depends on the amount of energy each part carries. With high frequencies and short wavelengths, and vice versa, the spectral distribution of radiation reaching Earth's surface and it can be divided into three main regions as follows:

1. Infrared with wavelengths greater than (0.7) micrometers.

2. The visible area with wavelengths of between $(0-75)$ micrometers.

3. The ultraviolet area with wavelengths is less than $(0,4)$ micrometers.

Light-ultraviolet is a part of electromagnetic light, it is located within the electromagnetic spectrum between visible light and $\mathrm{X}$-ray. The sun is only natural source of radiation Ultraviolet light penetrating a surface of the earth and divided according to their effects on three packages: ( UV-A is located within wavelengths 400 $315 \mathrm{~nm}$ ), (UV-B is located within wavelengths $315-280 \mathrm{~nm}$ ) and (UV-C is located within wavelengths 280 $100 \mathrm{~nm}$ ). About $9 \%$ of earth's rays are ultraviolet rays, and UV rays that reach earth's surface are $95 \%$ UVA and 5\% UVB and UVC are all reflected by the atmosphere. As well as more than $90 \%$ of UVB reflected by the ozone layer, water vapor, oxygen, and carbon dioxide. UVA is affected by very low conditions. Therefore, UVR of Earth's surface is composed largely of UVA with a small fraction of UVB [12].

\subsection{Biological benefits of ultraviolet radiation}

Biological effects of ultraviolet radiation on human health are generally classified into three categories: Bacterial effect (microbicides) [25], Absorption of radiation through the skin, which provides a local response and regular, and fall of light on retina leads to nerve signals, and these nerve signals are transmitted by a separate path from optical signals that affect many processes in the body. The effect of ultraviolet radiation is enough UV radiation in the sun throughout the year to kill bacteria and musty in outside air. Microorganisms usually love dark and moist places of their growth. The rate of destruction varies depending on the type of contaminants, mold, and spores have large sizes and higher survival rates, while microbes and viruses have the possibility of survival short under the same light, and in general, the sun can kill bacteria, and mould within one hour produce a sufficient health. The UV radiation causing microbial death in outside air. The effect and effectiveness of UV radiation depend on the presence of these wavelengths and duration of exposure. The UV's sterilization is a photochemical process. In the internal environment, contaminants are mainly composed of carbon compounds, these compounds decompose when exposed to UV radiation, they can destroy DNA for microorganisms and dissolve organic matter in internal air, and radiation must directly contaminate these pollutants for destruction. [9]

\subsection{Solarization factor standard on Educational buildings}

There are many determinants that play a role in directing administrative spaces, some of which emphasize avoidance of problems caused by direct sunlight and window into space of education and heterogeneous lighting, some specialists recommend avoiding them. From the book of Mark Vizovy Polyion the Roman architect, all buildings do not have a correct schematic description unless we consider it from the start the correct direction towards sun, angle of thought and space function. It is also useful here to see proposal of 
German architect (Jotgov) Solar exposure unit is solar clock any hour exposure to direct sunlight. If this fact was made for hundreds of years ago, its concept is now more complex and "more sophisticated" in calculations, where new changes must be taken into account to determine the solarization criterion within space [13] Different standards have been adopted for solarization of space in many countries. British Standard BSI Institution recommends sunlight in buildings in the United Kingdom but it does not give any indication of size or shape of windows, nor it's not included in sun health requirements. But the fact of determinants of health requirements emphasize need for space for a minimum period (1 hour / day) within warm regions, especially during winter and moderate seasons, taking into account the greater duration of solarization and in a few quantities was better than health side, in our warm country, solarization criterion is based on balance between two real things: First controlling temperature and the needs for radiation to meet atmosphere. Second the budget process will rely heavily on geographical area latitude and chronology of climate change as well as planning and design decisions in collection and routing of buildings. [12] Standardization estimates the duration of precipitation (hour) perfectly, as well as the number of cubic meters of sunlight from space relative to the size of space, regular movement of the sun, daily and quarterly and repeat within specified times of the year. The largest impact on the possibility of design solutions that respond to this movement in order to achieve optimal exploitation of possibility of the sun in summer and winter to meet the growing needs of them.[9]

\section{Mathmatical Model}

\subsection{Measure efficiency of solar exposure}

The idea of the mathematical approach to measuring the efficiency of windows is based on providing solar exposure to sterilize spaces of educational buildings with different areas. The basis of calculating number of sun-hours and size of direct solar ray, which is formed in space (representing size of sterilized air) through percentage of different windows of eight directions (m3) and thermal energy units (W/ $\mathrm{m} 3$ ) is the UV sterilization process that depends on frequencies of these lengths wave radiation connecting to amount of power (in watts / m2), where these lengths are breaking bonds between molecules (DNA) of pollutants [26].

\subsection{Lighting homogeneity}

The homogeneity of illumination can be defined as the efficiency of lighting values of illumination or degree to which values of light levels in a unit of lux that equal to a particular surface or in a specific place. Illumination is also homogeneous in form of indirect illumination and is distributed almost evenly throughout space "without any difference in light [23].

\subsection{Homogenization factor of lighting}

Homogenization factor is defined as the ratio of minimum illumination to average illumination of all points on the working surface within space. When homogenization value is equal to (0.5), it is considered to be an ideal and standard value according to global standards [Berhad ,Sirim,2002] and (0.4) While value of lighting homogeneity is very high if it reaches (0.7), knowing that the eye does not notice a difference when homogeneity value of lighting levels is equal to (0.5) [27].

\subsection{Area of Window}

To determine the area of the windows in different geographical directions of the building that has a great effect in controlling sun's rays, we find that all previous studies that gave values for windows in different directions for the purposes of controlling sun and for the efficiency of thermal windows performance with neglected sides is most importantly for health aspect. These values were not representative of appropriate space areas. To provides these requirements in a single goal and for gain balance between various requirements of windows in buildings to provide natural lighting, natural ventilation and external view, in 
addition, the need to provide solar exposure to internal spaces, which has great health impact in the quality of the environment and internal air for education building type. Therefore, it is necessary to obtain a percentage of the area of windows relative to the area of space floor, depending on health base of solar exposure and balancing these values with values proposed to achieve thermal requirements and natural ventilation to give values that meet various requirements for exit or entry of air.[28]. Space of windows effects on the amount of natural light and best the space for any window is approximately $8 \%$ to $10 \%$ from total space area to provide adequate lighting levels without glare in the vicinity of windows. The objective of window size is to determine the effect of changing percentage of the grid on demand for heating and cooling energy therefore, the increase in the area of windows leads to increasing temperature inside the building. In cold areas, double glass is used to reduce the thermal value of glass. These material made by windows affect the amount of solar radiation during which [23].

\subsection{Selection area of window ratio space area}

A study has generally used two methods to determine an appropriate suitable area in a different type of buildings. First method defines an area of glazing as a percentage of outer wall area. This method has been used in most studies to find appropriate ratio to reduce gain and loss of heat, it is balancing between values of thermal load of window for each of walls in different directions, while the second method defines the area of glazing as a proportion of building area of building, and percentage of glazing specified in these studies vary climatic conditions of area, second one most efficient for adoption in reaching appropriate verification ratios for purposes of solar sterilization that sterile area calculation will depend on solar spot formed in space which that have a direct impact on sterilization [28].

\section{Methodology}

This study is based on evaluating the status of three local school buildings types for Mosul municipality, which are represents random orientation for their locations, Fig $(1,2,3)$. The issues that evaluating and measuring the practical study are the design characteristics' related to health aspects of daylight factors, which are applied to main characteristics that work to provide health internal environment. The daylight factor was studied through two main issues in health effects of educational buildings namely:

1. The factor of radiation solar daylight or solarization. Its impact concentrated on the quality of indoor air as well as the level of sterilization for health purposes and because it is conceded as windows its main outlet is providing solar radiation and fresh air for all building classrooms.

2 - Homogeneity factor in daylighting entered as one of the important factors in raising the efficiency of educational performance for students occupies classroom space, and the only light in hours of work assigned.

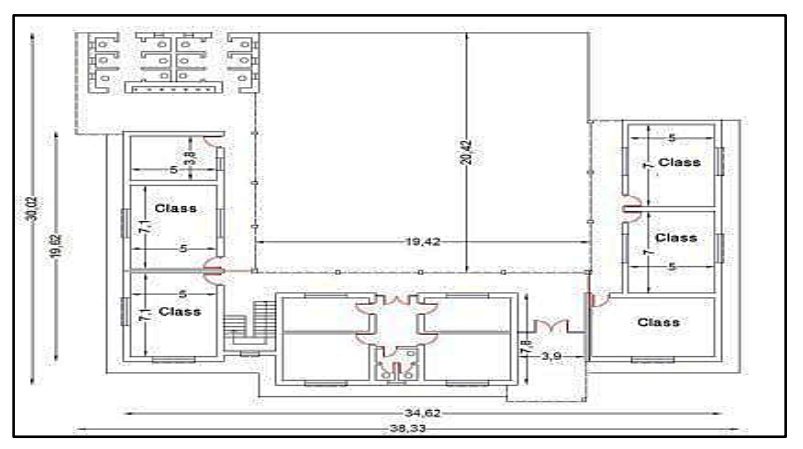

Figure. 1. School building of Mosul city -type-1

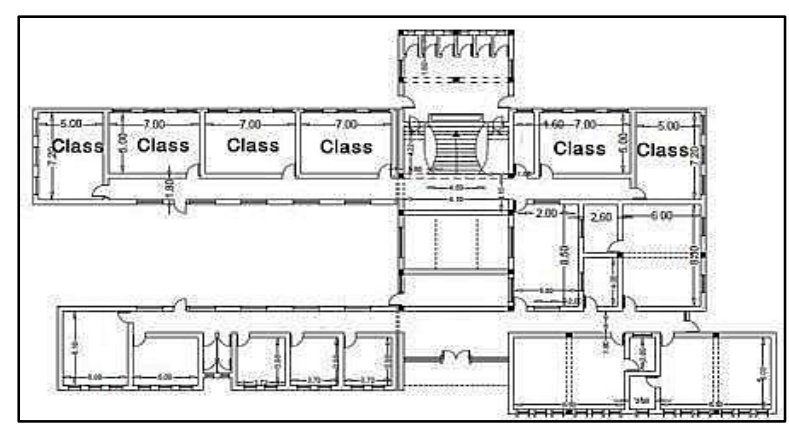

Figure 2. School building of Mosul city -type-2 


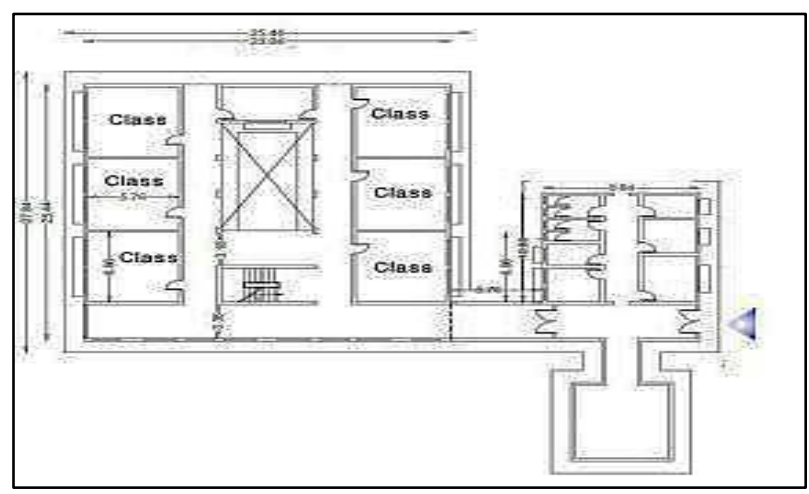

Figure 3. School building of Mosul city -type-3

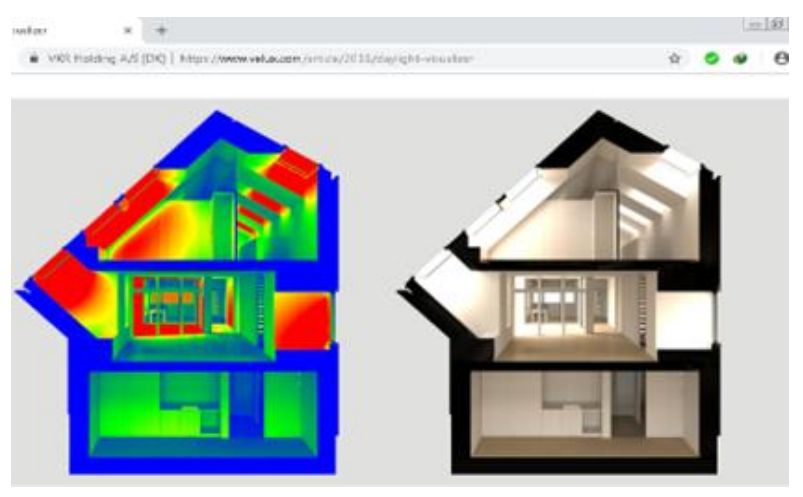

Figure 4. Velux Daylight Visualizer 2012

\subsection{Day lighting measurements methods}

The VELUX Daylight Visualizer measurement tool is a professional lighting simulation tool for the analysis of daylight conditions in buildings. It is intended to promote the use of daylight and to aid professionals by predicting and documenting daylight levels and appearance of a space prior to realize the building design. The differences between daylight visualize and commonly used 3D visualization programs are permitted it to accurately simulate and quantify daylight levels in interiors, whereas $3 \mathrm{D}$ visualization programs only generate images without information about the quantity of light in a given space .Fig(4).

\subsection{Calculates of effective solarizaition of classes on three type of schools}

The effective surface area of the three school types is calculated by measuring the area of light falling on the working surface and in each row of square meters in the horizontal plan by using Velux application output after converting it to Acad program and for the eight main and sub-directions, 12-december, 21-march at 10 am. The output of structure plan of three type (models) and the data are entered in Table (1), Fig $(5,6,7)$ then the percentages of the effective areas are calculated as follows:

Percentage of active areas per type $=$ total number of active areas in class $\backslash$ total classes areas.

\section{Discussions}

The south and south-east directions achieved a higher solarization of class in the three patterns, while northeast and north-west directions achieved less solarization of class in the three patterns. In general, the solarization area increased during the spring equinox due to the rise in the angle of the sun rise. The increase in exposure area is noticeable in the third type of schools in spring equinox. This is because of symmetry in the distribution of classes, Fig (6), which makes the solar radiation more distributed in three classes compared to the other three. This is only pattern that achieves homogeneity in value of solarization at in spring equinox. The values of solar areas are approximated when the orientation is changed. In the second type of school, the solarization area changes significantly as the orientation changes from north to south to achieve a lower to the highest value compared to other models because of arrangement of classes on a single line that makes the process of receiving solar radiation equal, while increase at southern route and then return to fall again at western direction. The first type of school is similar to the third type in terms of effective solarization area, especially during the winter solstice and at the north, north-east and south-east directions due to nearsymmetrical shape. However, the solarization area is less than the second type in the southern and western directions, in period of spring equinox also .Figure $(11,12)$ show the differentiation between the three type of schools in terms of solarization area and the best orientation. 


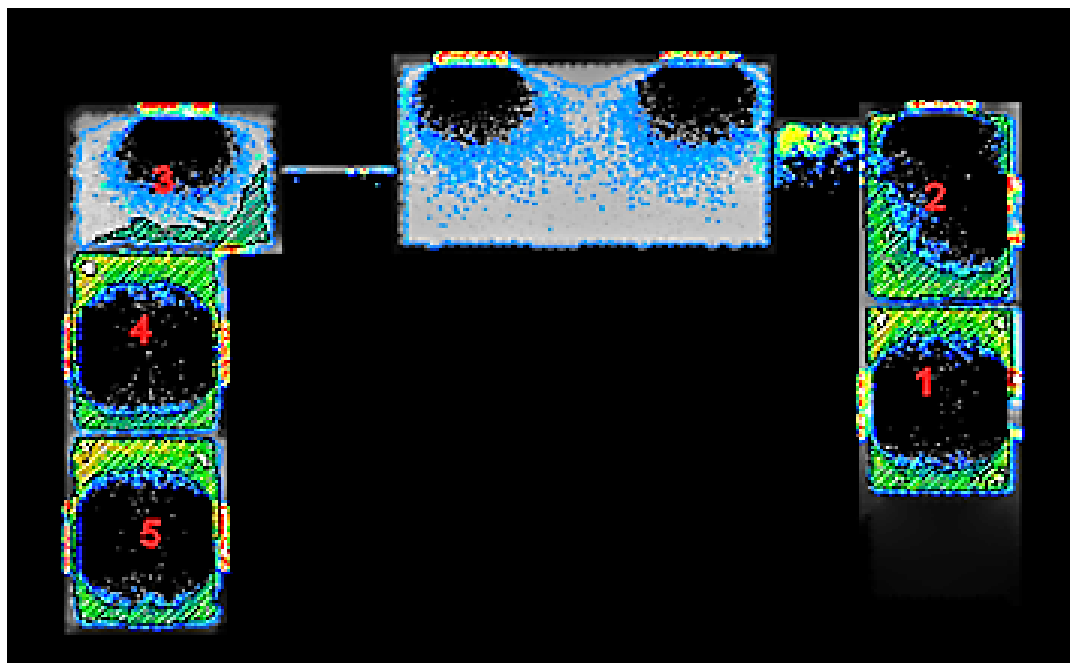

Figure 5. explain ground plan for school type1 render by (Velux) at 21-3-10 A.M. (North direction) and showing the effective area hatching by (Autocad) for the numbered classes

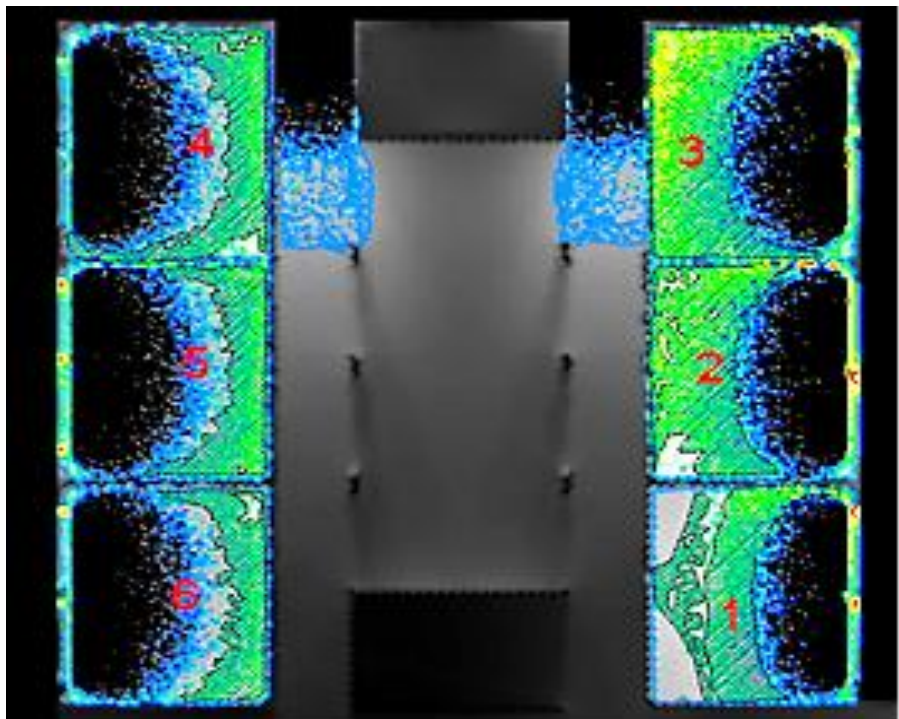

Figure 6. Explain ground plan for school type3 render by (Velux) at 21-3 -10 A.M. (North direction) and showing the effective area hatching by (Autocad) for the numbered classes

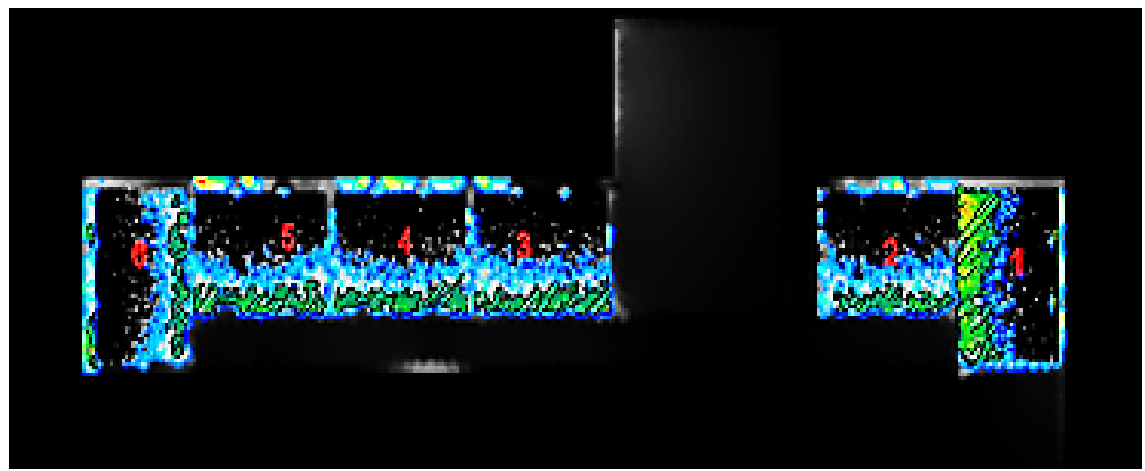

Figure 7. Explain ground plan for school type2 render by (Velux) at 21-3-10 A.M. (North direction) and showing the effective area hatching by (Autocad) for the numbered classes

Figure $(8,9,10)$ illustrates the effective areas ratios by changing direction for school types at (10A.M).Figure $(11,12)$ effective areas ratios by changing direction for three types at 22-Dec.and at 21-March. (10 A.M) 


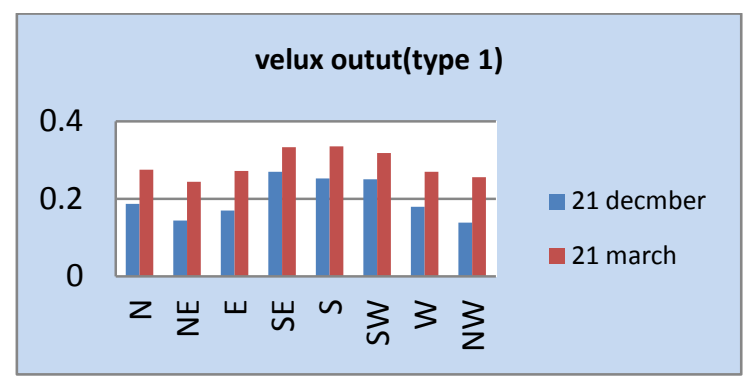

Figure 8. Average of solarization at two seasons on building type 1

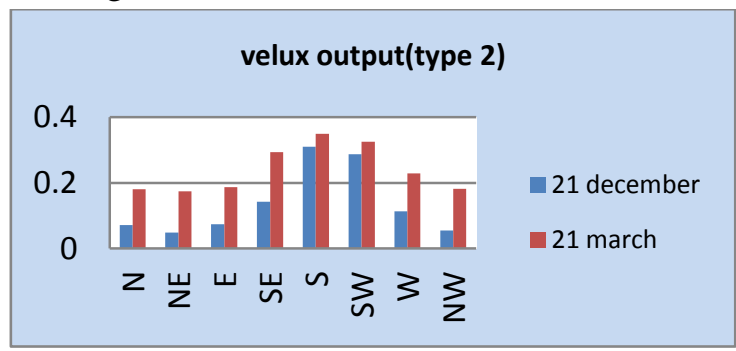

Figure. 9. Average of solarization at two seasons on building type 2

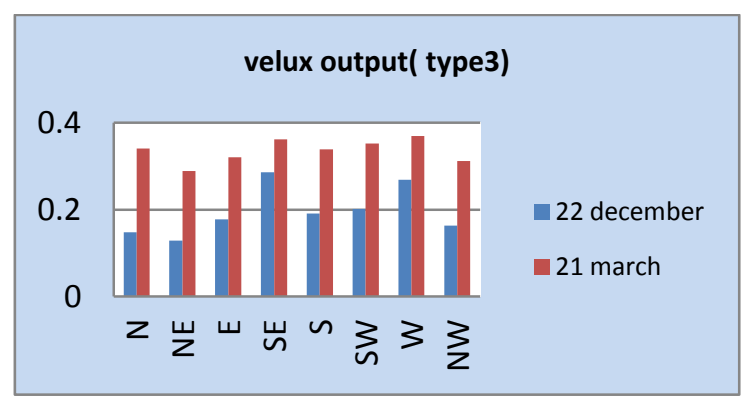

Figure 10. Average of solarization at two seasons on building type 3

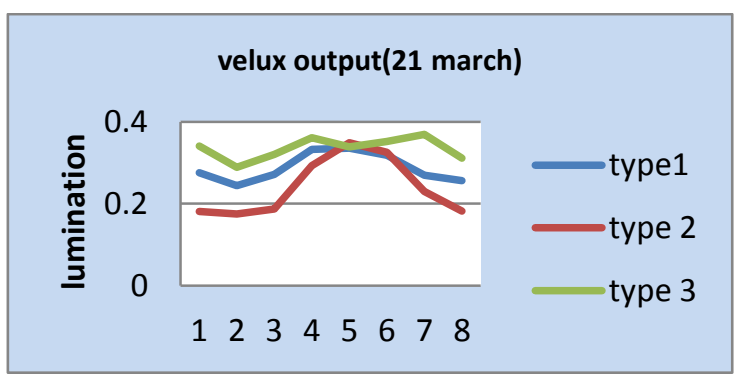

Figure 11. Variance of solarization of three building types at March

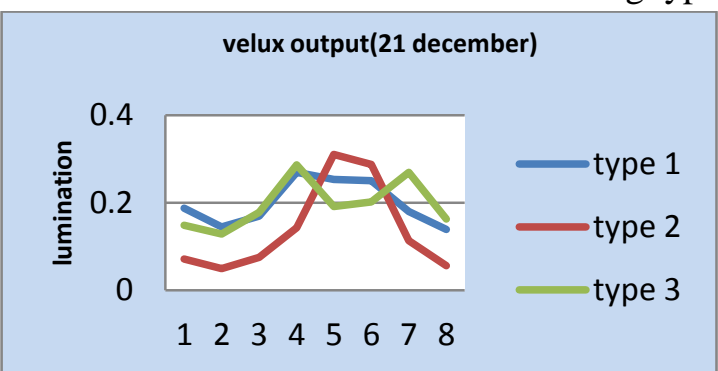

Figure 12. Variance of solarization of three building types at December

\subsection{The measurements of day lighting Homogeneity are achieves by two approaches as flow :}

1. Homogeneity of daylight illumination values at working surface according to different dimensions of 
windows in the same typical classroom (w1,w2,w3,w4,w5), during 10 o'clock in 21th of March and 21th of December as suitable time of lumination, at southeastern orientation, where the values represent STDE of all average values that indicate by velux output, Tables (2), Figure(13,14). Table (4) illustrates details.

2. Homogeneity of daylight values at working surface according different additional element outside window (trees, small trees, horizontal lover, vertical lover, combined lovers $15-30 \mathrm{~cm}$,light shelves), during 10 o'clock in 21th of March and 21th of December as suitable time of lamination, at southeastern orientation, the values represent STDE of all average values that indicate by velux output, Table (3), Figure $(15,16)$, Table (5) illustrate details.

\section{Discussion:}

The results of output of velux tool indicates that the use of different dimension of windows affected homogeneity of daylighting over workplace of classroom. W3 is the best one that achieves suitable homogeneity of daylighting according two seasons (21march, 21december) at southeastern orientation of building Figure.(13,14).

The results of output of velux tool indicates that the use of different additional elements of windows was not affected clearly on homogeneity day lighting of classroom, with main suitable orientation of building. Figure. $(15,16)$. that indicates the user of additional element $s$ are secondary factor of design windows details.

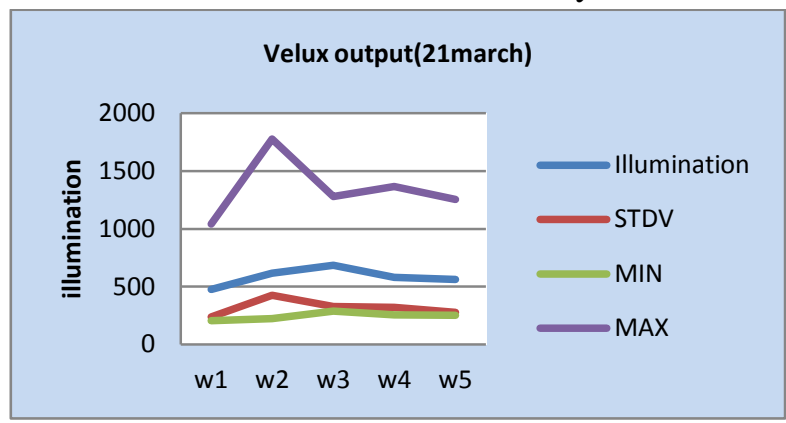

Figure 13.Variance of homogeneity illumination according windows dimensions-21 March

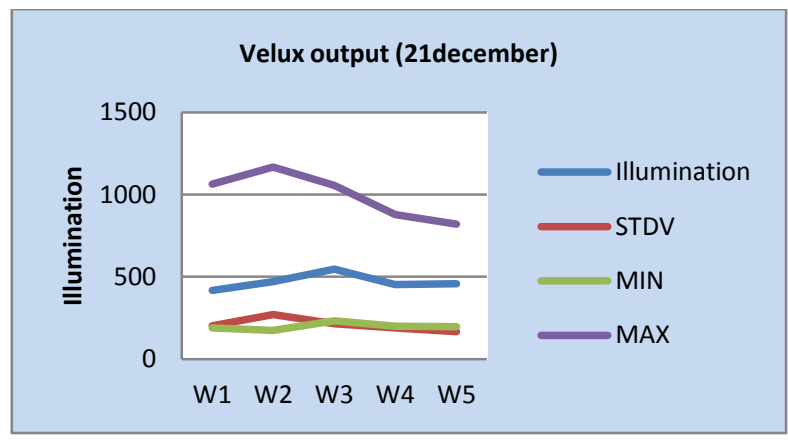

Figure 14. Variance of homogeneity illumination according windows dimensions-21 December.

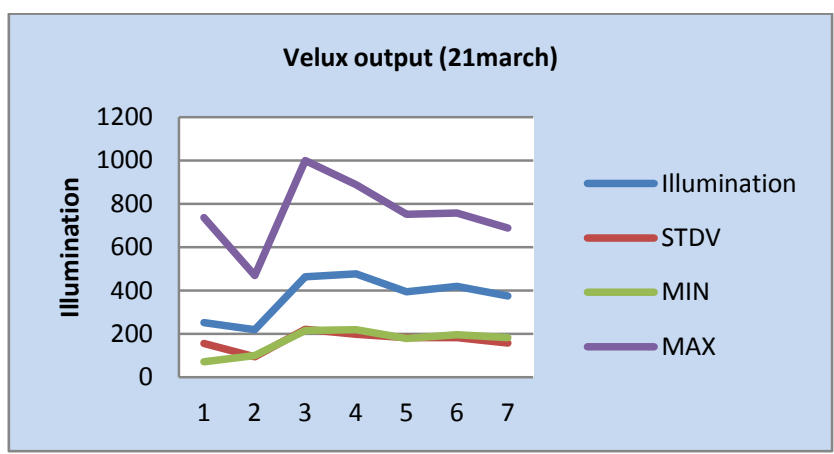

Figure 15. Variance of homogeneity illumination according additional daylight elements -21 March . 


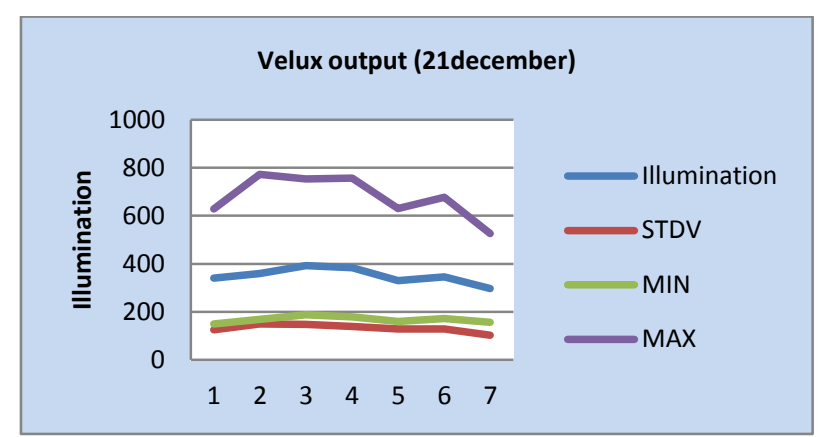

Figure 16. Variance of homogeneity illumination according additional daylight elements -21 December.

\section{Conclusions:}

1. The environmental characteristics of the local schools in Mosul city have been describing by irregularity and non-directionality. Most schools are implemented according to other factors such as Public Street, main entrances and even size of the plot without paying attention to the proper orientation of the daylighting that required for school buildings.

2. The software applications (velux) can be adopted as an important measurement tool for environmental characteristics that are difficult to measure by traditional experimental means. It provides a virtual environment for all possible characteristics of the internal environment by building a virtual model closer to reality with the possibility of controlling the quality and quantity of measured light.

3. The optimum values of the solarization factor in the school buildings are related to the multi-direction of school classes for more than one direction (central pattern, unexpended) in order to obtain the largest amount of solar radiation in multiple directions from east to west. The amount of radiation is limited in an extended pattern of classes.

4. The optimum values of the daylight homogenization factor for the work surface of the classroom is related to extending horizontal windows uninterrupted for the widest possible distance. To achieve the highest horizontal balance in the amount of radiation inside in accordance according to sun movement, where the separated windows are cut and divides radiation inside, which loses the appropriate congruence required.

5. The natural lighting has obvious lack effect on homogenization factors level due to various additional elements on the working surface level. These factors working in a stable position and natural lighting moving according to the movement of the sun, so their use is an integral and not essential in achieving optimal homogeneity of lighting.

Table 1. Explain the effective area $\left(\mathrm{m}^{2}\right)$ on work surface for the classes at $(10 \mathrm{am}$.) for types $1-2-3$

\begin{tabular}{|c|c|c|c|c|c|c|c|c|c|}
\hline \multirow[t]{2}{*}{ date } & \multirow[t]{2}{*}{ class } & \multicolumn{8}{|c|}{ School direction (type1) } \\
\hline & & North & North-east & East & South-East & South & South-West & West & $\begin{array}{l}\text { North- } \\
\text { West }\end{array}$ \\
\hline \multirow{6}{*}{$\frac{1}{\mathfrak{1}}$} & 1 & 9.04 & 9.08 & 8.7 & 9.56 & 6.61 & 8.0 & 9.4 & 7.86 \\
\hline & 2 & 5.34 & 2.57 & 7.0 & 11.77 & 11.3 & 8.1 & 3.47 & 2.83 \\
\hline & 3 & 0 & 0.39 & 0 & 6.9 & 15.57 & 15.2 & 1.8 & .26 \\
\hline & 4 & 7.92 & 6.62 & 8.09 & 8.4 & 3.85 & 5.99 & 7.88 & 6.4 \\
\hline & 5 & 10.73 & 6.8 & 6.08 & 10.85 & 7.21 & 6.8 & 9.1 & 7.05 \\
\hline & $\begin{array}{l}\text { Effective } \\
\text { ratio }\end{array}$ & 0.1876 & 0.1446 & 0.16971 & 0.2697 & 0.2530 & 0.2505 & 0.1798 & 0.1386 \\
\hline \multirow{3}{*}{$\frac{m}{n}$} & 1 & 11.08 & 11.2 & 10.4 & 11.48 & 10.4 & 11.16 & 11.24 & 10.82 \\
\hline & 2 & 10.62 & 8.9 & 10.8 & 12.3 & 11.73 & 10.04 & 7.78 & 8.94 \\
\hline & 3 & 4.66 & 3.8 & 4.9 & 13.68 & 18.8 & 14.83 & 8.17 & 4.05 \\
\hline
\end{tabular}


PEN Vol. 7, No. 3, September 2019, pp.1354- 1372

\begin{tabular}{|c|c|c|c|c|c|c|c|c|c|}
\hline & 4 & 10.62 & 9.13 & 11.2 & 10.13 & 8.36 & 9.4 & 9.593 & 10.05 \\
\hline & 5 & 11.52 & 10 & 10.6 & 11.07 & 9.85 & 10.59 & 10.74 & 11.26 \\
\hline \multirow{3}{*}{ date } & $\begin{array}{l}\text { Effective } \\
\text { ratio }\end{array}$ & 0.2755 & 0.2444 & 0.2721 & 0.3332 & 0.3360 & 0.3182 & 0.270 & 0.2563 \\
\hline & class & \multicolumn{8}{|c|}{ School direction(type2) } \\
\hline & & North & North-east & East & South-East & South & South-West & West & $\begin{array}{l}\text { North- } \\
\text { West }\end{array}$ \\
\hline \multirow[b]{7}{*}{ ปั่ } & 1 & 9.43 & 0.88 & 10.74 & 15.83 & 9.18 & 1.64 & 0.84 & 0.54 \\
\hline & 2 & 0.98 & 1.17 & 0.91 & 3.96 & 13.96 & 11.79 & 0.73 & 0.95 \\
\hline & 3 & 1.52 & 1.81 & 1.36 & 2.28 & 14.85 & 13.82 & 4.04 & 1.72 \\
\hline & 4 & 1.28 & 1.26 & 1.04 & 4.13 & 13.55 & 12.87 & 1.91 & 1.04 \\
\hline & 5 & 1.79 & 1.19 & 1.58 & 3.56 & 13.83 & 13.25 & 2.37 & 1.12 \\
\hline & 6 & 0.17 & 4.05 & 0.21 & 0.46 & 0.32 & 7.61 & 14.11 & 6.43 \\
\hline & $\begin{array}{l}\text { Effective } \\
\text { ratio }\end{array}$ & 0.0715 & 0.0488 & 0.0747 & 0.1425 & 0.3098 & 0.2876 & 0.1132 & 0.0556 \\
\hline \multirow{9}{*}{$\begin{array}{l}\frac{r}{d} \\
\text { date }\end{array}$} & 1 & 13.21 & 9.3 & 15.04 & 14.33 & 10.48 & 4.73 & 6.12 & 7.41 \\
\hline & 2 & 3.99 & 4.26 & 4.53 & 10.55 & 14.56 & 12.22 & 4.7 & 4.4 \\
\hline & 3 & 5.82 & 5.51 & 5.34 & 10.58 & 15.38 & 14.4 & 9.94 & 6.56 \\
\hline & 4 & 5.17 & 5.68 & 5.19 & 11.69 & 14.07 & 13.31 & 6.66 & 6.26 \\
\hline & 5 & 5.6 & 5.05 & 6.19 & 10.83 & 14.27 & 11.69 & 7.35 & 5.55 \\
\hline & 6 & 4.6 & 7.24 & 3.36 & 4.13 & 5.25 & 12.63 & 13.88 & 8.5 \\
\hline & $\begin{array}{l}\text { Effective } \\
\text { ratio }\end{array}$ & 0.1810 & 0.1747 & 0.1870 & 0.2929 & 0.3491 & 0.3253 & 0.2294 & 0.1824 \\
\hline & class & \multicolumn{8}{|c|}{ School direction(type3) } \\
\hline & & North & North-east & East & South-East & South & South-West & West & $\begin{array}{l}\text { North- } \\
\text { West }\end{array}$ \\
\hline \multirow{7}{*}{ ปี } & 1 & 2.08 & 0 & 4.02 & 12.85 & 8.35 & 0.1 & 0.05 & 0 \\
\hline & 2 & 9.22 & 0.45 & 10.86 & 18.66 & 10.73 & 1.16 & 4.65 & 0.7 \\
\hline & 3 & 12.31 & 1.83 & 16.73 & 20.8 & 13.96 & 3.99 & 3.88 & 1.81 \\
\hline & 4 & 4.92 & 11.04 & 4.25 & 7.29 & 5.32 & 17.76 & 21.22 & 13.32 \\
\hline & 5 & 4.35 & 9.02 & 4.19 & 5.12 & 4.63 & 13.25 & 17.15 & 11.52 \\
\hline & 6 & 2.78 & 8.62 & 2.77 & 4.16 & 2.96 & 12.19 & 17.79 & 11.85 \\
\hline & & 0.1482 & 0.1287 & 0.1780 & 0.2864 & 0.1910 & 0.2014 & 0.2691 & 0.1629 \\
\hline \multirow[b]{7}{*}{$\stackrel{m}{n}$} & 1 & 14.52 & 4.21 & 11.84 & 16.05 & 10.97 & 9.86 & 10.38 & 2.77 \\
\hline & 2 & 16.33 & 9.48 & 16.14 & 18.08 & 14.58 & 8.36 & 11.5 & 9.75 \\
\hline & 3 & 20.06 & 11.44 & 20.33 & 22.1 & 18.39 & 10.55 & 11.15 & 10.9 \\
\hline & 4 & 12.22 & 16.53 & 10.74 & 12.05 & 15.84 & 20.8 & 20.84 & 19.92 \\
\hline & 5 & 10.14 & 15.44 & 9.38 & 9.94 & 11.99 & 17.34 & 17.21 & 15.91 \\
\hline & 6 & 8.62 & 12.32 & 8.58 & 8.69 & 9.7 & 17.75 & 17.78 & 15.75 \\
\hline & $\begin{array}{l}\text { Effective } \\
\text { ratio }\end{array}$ & 0.3404 & 0.2886 & 0.3202 & 0.3613 & 0.3387 & 0.3520 & 0.3694 & 0.3118 \\
\hline
\end{tabular}

Table 2. Average values of illumination on 5 types of windows on typical classroom

\begin{tabular}{cccccccccccc} 
Velux output & \multicolumn{4}{c}{ W1 } & \multicolumn{2}{c}{ W2 } & \multicolumn{2}{c}{ W3 } & \multicolumn{2}{c}{ W4 } & \multicolumn{2}{c}{ W5 } \\
\cline { 2 - 13 } & dec & mrc & dec & mrc & dec & mrc & dec & mrc & dec & mrc \\
Illumination level & 418 & 474 & 470 & 615 & 547 & 684 & 454 & 582 & 458 & 563 \\
STEDV & 201 & 239 & 269 & 427 & 214 & 329 & 190 & 322 & 167 & 279 \\
\hline
\end{tabular}


PEN Vol. 7, No. 3, September 2019, pp.1354- 1372

\begin{tabular}{ccccccccccc}
\hline MIN & 188 & 206 & 174 & 224 & 232 & 288 & 200 & 255 & 196 & 251 \\
MAX & 1063 & 1042 & 1167 & 1776 & 1057 & 1281 & 878 & 1366 & 820 & 1253 \\
Min/Max & 0.18 & 0.2 & 0.15 & 0.13 & 0.22 & 0.22 & 0.23 & 0.19 & 0.24 & 0.2 \\
\hline
\end{tabular}

dec: December mrc: March

Table 3. Additional Delighting Elements for typical window (w1)

\begin{tabular}{|c|c|c|c|c|c|c|c|c|c|c|c|c|c|c|}
\hline \multirow[t]{2}{*}{$\begin{array}{l}\text { Velux } \\
\text { output }\end{array}$} & \multicolumn{2}{|c|}{ trees } & \multicolumn{2}{|c|}{$\begin{array}{c}\text { Small } \\
\text { trees }\end{array}$} & \multicolumn{2}{|c|}{$\begin{array}{l}\text { Light } \\
\text { shelves }\end{array}$} & \multicolumn{2}{|c|}{$\begin{array}{c}\text { Horizontal } \\
\text { lovers }\end{array}$} & \multicolumn{2}{|c|}{$\begin{array}{l}\text { Vertical } \\
\text { lovers }\end{array}$} & \multicolumn{2}{|c|}{$\begin{array}{c}\text { combined } \\
\text { lovers-15 } \\
\text { CM }\end{array}$} & \multicolumn{2}{|c|}{$\begin{array}{c}\text { combined } \\
\text { lovers-30 } \\
\text { CM }\end{array}$} \\
\hline & Dec & $\mathrm{mrc}$ & dec & $\mathrm{mrc}$ & dec & $\mathrm{mrc}$ & dec & mrc & dec & mrc & dec & mrc & dec & $\mathrm{mrc}$ \\
\hline Illuminatio & 341 & 253 & 360 & 220 & 393 & 463 & 384 & 478 & 329 & 394 & 345 & 420 & 296 & 375 \\
\hline STEDV & 125 & 156 & 149 & 94 & 148 & 221 & 139 & 198 & 129 & 183 & 128 & 183 & 103 & 158 \\
\hline MIN & 149 & 71 & 168 & 101 & 187 & 216 & 179 & 219 & 160 & 180 & 172 & 197 & 156 & 183 \\
\hline MAX & 628 & 737 & 772 & 469 & 754 & $\begin{array}{l}100 \\
0\end{array}$ & 757 & 888 & 631 & 752 & 677 & 758 & 526 & 689 \\
\hline Min/Max & $\begin{array}{l}0.2 \\
4\end{array}$ & 0.1 & $\begin{array}{l}0.2 \\
2\end{array}$ & $\begin{array}{l}0.2 \\
2\end{array}$ & $\begin{array}{l}0.2 \\
5\end{array}$ & 0.22 & 0.24 & 0.25 & 0.25 & 0.24 & 0.25 & 0.26 & 0.3 & 0.27 \\
\hline
\end{tabular}

\section{Conflict of Interest}

The authors declare no conflicts of interest.

\section{Funding}

No funding was received for this project.

\section{References:}

[1] Abdul-Latteef ,Farah Salah ,The Impact of Random Locating of School Buildings in Effective Natural Lighting For Classroom Evaluate Reality of Local Types of Schools- Mosul As a Partial Fulfillment of Requirements For the Degree of Higher Diploma, university of Mosul ,architecture department , 2014

[2] Alalwan , Huda Abdlsaheb , (2017) "Architectural Harmony with Nature "Emarat journal for engineering research, Vol.1,22,p55-37,.

[3] Usta,Pinar ,\& other, "Sustainability of Traditional Building Located in Rural Area "Periodical of engineering and Natural Sciences, Vol.5,No.2,2017,pp231-236 .

[4] Kim J. \& Rigdon , B, " Sustainable Architecture Module: Introduction to Sustainable Design(1988) " , University of Michigan ,National pollution center for Higher education , pp. 1,5,14

[5] Husein, Shaimaa Hameed,\& other, "Urban Regeneration through Post-war reconstruction :Reclaiming the urban identity of old city of Mosul "Periodical of engineering and Natural Sciences ,Vol.7,No.1,2019,pp294-301.

[6] Al-Rubaye, Ali Saad, \& other, " Architectural requirements of people with disability in the urban cities in Iraq "Periodical of engineering and Natural Sciences ,Vol.7,No.3,2019,pp139-1254 .

[7] Levin ,H. (1995) " Building Ecology :An Architect s Perspective on Healthy Building " .

[8] Findik,Fehim.”Green Material and Application “ „Periodical of engineering and Natural Sciences ,Vol.3,No.2,2015 .

[9] EPA : Environmental Protection Agency.(1990) " Sick building syndrome : indoor air facts, air and radiation, Research and Environment ", U.S.

[10] Sassi P. (2006)," Strategies for Sustainable Architecture" , Taylor \&Francis , New York , p.112,97,96,9,15. 
[11] Aljawadi, Meqdad Haider,( 2010) " Healthy Architecture : healthy roles in choice dimension of window in office building " Iraq journal for architectural engineering, Vol.6, No.19

[12] Elia \&odor (1983), " New health hazards in sealed building " AIA Journal April.

[13] Gary , Raw,(1996) " Healthy building " journal of social and environmental engineers , Vol.9. No.4 December.

[14] Lee, T.G.(1996), et al. "Health and built environment : Indoor Air quality signs , Curriculum material project , Faculty of environmental design , University of Calgary .

[15] Welton , J.(2007), " living Element of Healthy building design, New York, USA .

[16] Halilovic , Maida, "Potential of air quality improvement in Sarajevo usng innovative architectural approach “,Periodical of engineering and Natural Sciences ,Vol.5,No.2,2017,pp128-135 .

[17] Saleem , Younis Mahmoud,(2009)" Effect of Outside Design Element in Daylight level impact on windows " ", Iraq journal for architectural engineering, Vol. 5,18.

[18] David M. Egan \&Victor W. Olgyay ,(2002) " Architectural Lighting " 2nd edition , Mc Graw-Hill , New York.

[19] Peter Boyce.(2003) " Benefits of Daylight through windows " Department of Energy.

[20] William , Pierpoint ,(1983) " A Simple Sky Model for Daylighting "

[21] Environmental Building News (1999)" Daylighting : Energy and Productivity Benefits " , Vol.8, No.9, Sept.

[22] Muhaisen, Ahmed \&Dabbor Hazem ,2015) " Studying impact of orientation, size and glass material of windows " Islamic university . journal of architecture and planning, Vol.27(1),pp1-15.

[23] Saleem . Younis Mahmoud ,(2017) "Employing natural lighting systems technology in raising environmental efficiency in educational building", Iraq journal for architectural engineering, Vol. 3.

[24] Hansen, Veronica Garcia ,(2006)" Innovative Daylighting Systems for Deep-plan Commercial building "Ph.D. Queensland University of Technology ,p.32,64.

[25] Derek, O. \& Roger, G.(2002) " Introduction to building " Pearson Education Limited.

[26] Jones , A. P(2004). " Indoor air quality and health " air pollution science for 21st century, Elsevier Ltd.

[27] Chai-Kwong, Mak .(2006) " public lighting design manual " 2nd addition ,Garden Road, Central , Hong-Kong, p36.

[28] Harkness . L.(1987) , " Solar radiation control in building " London, Applied Science Publishers , LTD. 


\section{Appendix:}

Table 4. Types of windows according their size and positions

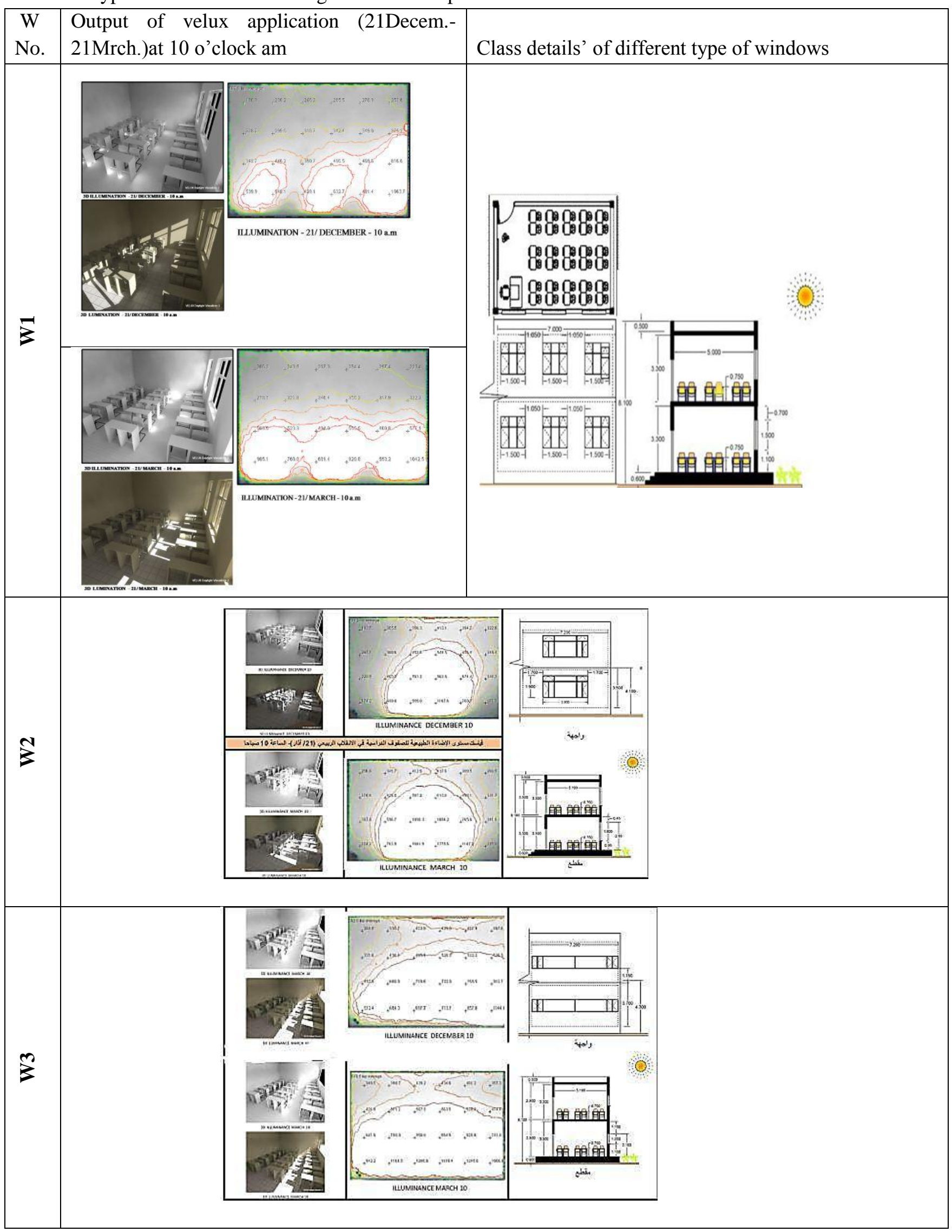




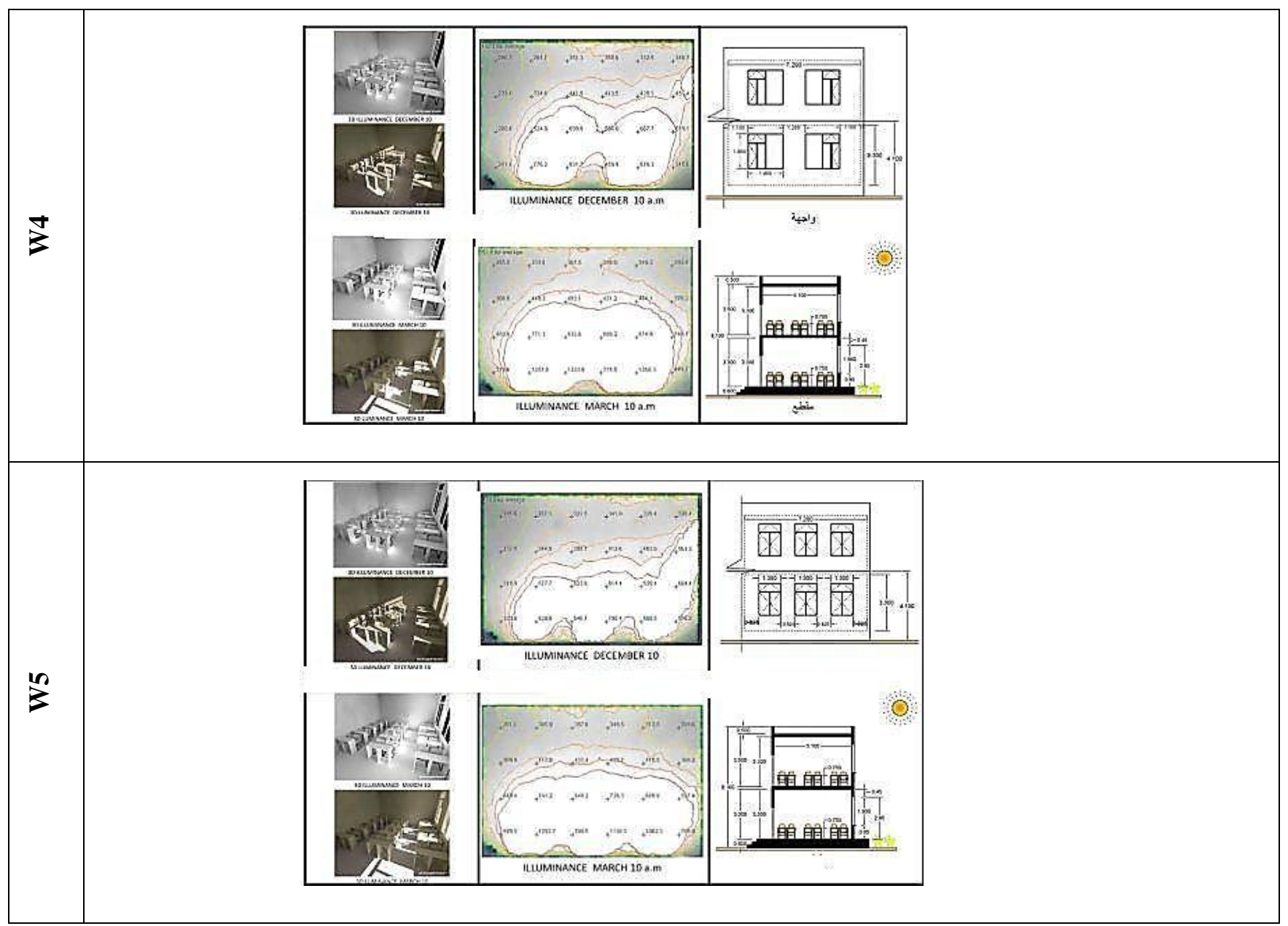

Table 5. daylight additional elements for typical window

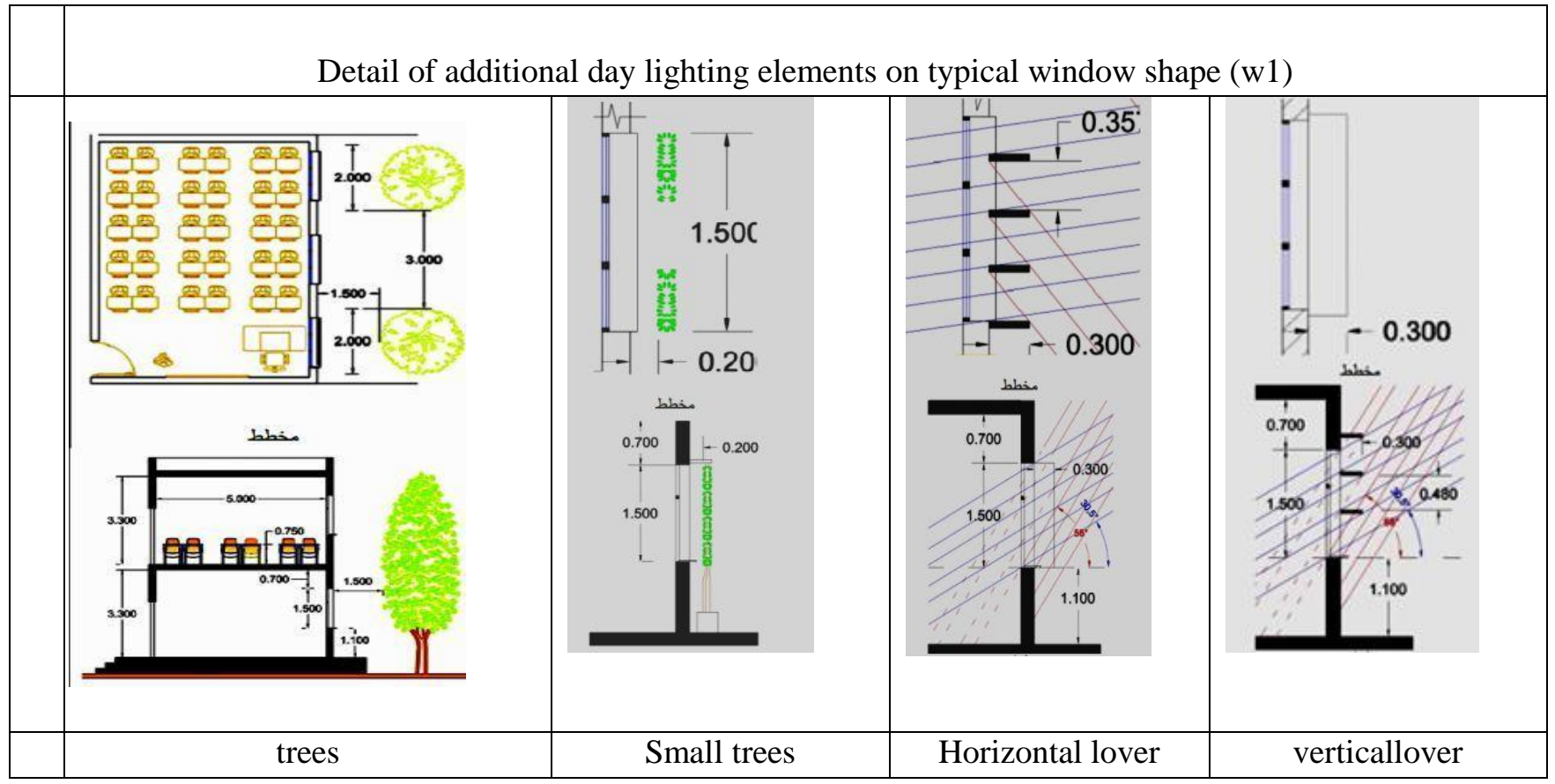




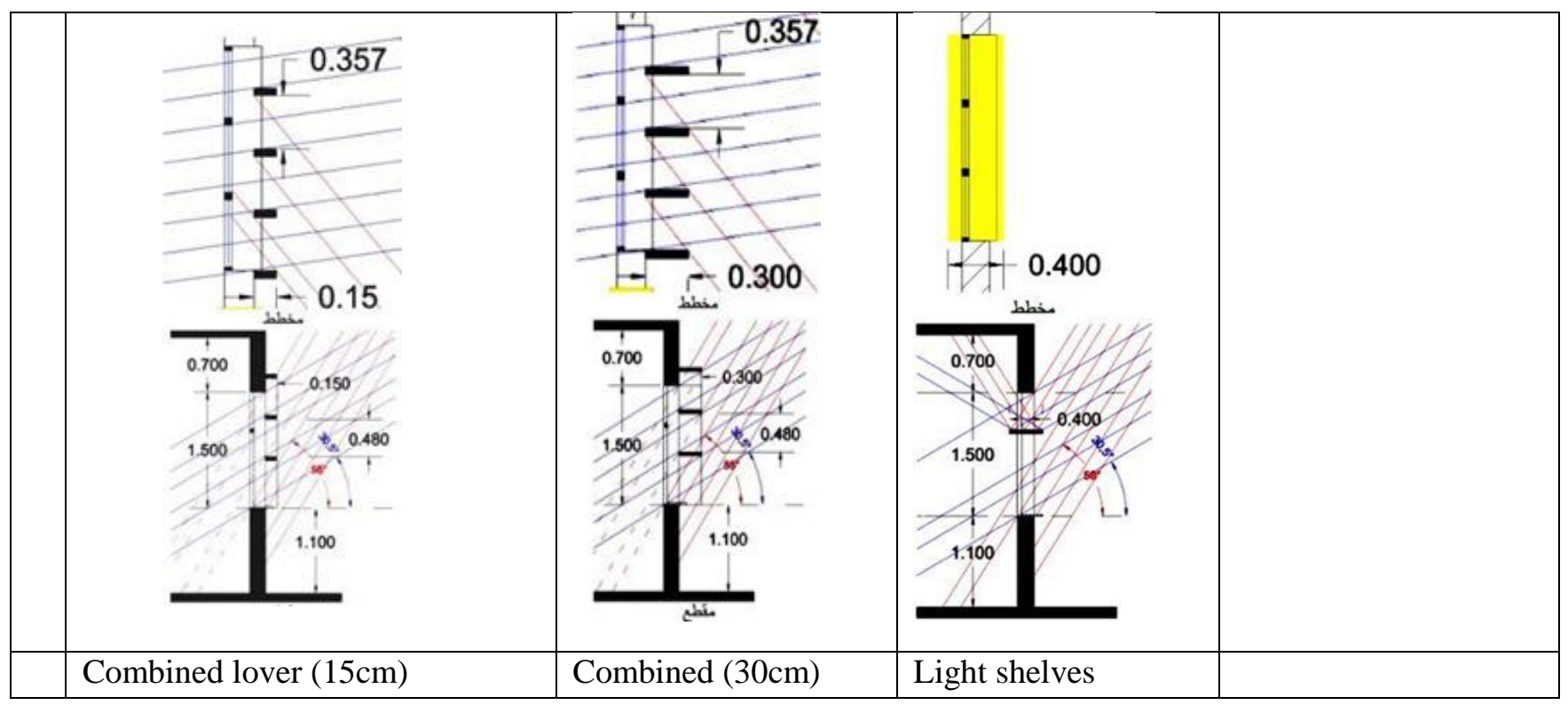

